\title{
The protein requirements of Nigerian peasant farmers
}

\author{
By B. M. NICOL \\ Nutrition Unit, Federal Medical Department, Nigeria \\ (Received I9 November 1958-Revised 9 April 1959)
}

A previous paper (Nicol, 1959) described the methods used to measure the food consumption of seven racially similar negroid rural Nigerian communities, and compared the estimated calorie value of these diets with the calorie requirements of different age and sex groups calculated according to the recommendations of the F.A.O.: Second Committee on Calorie Requirements (1957). It was found that the calculated requirements agreed well with estimated consumption provided the communities did not have to expend excessive amounts of energy in the course of their day-to-day existence, and provided that food supplies were normally available. Children less than I3 years of age seldom received enough food to supply their estimated need for energy.

This paper considers the adequacy of the protein in these rural Nigerian diets, assessed by the methods recommended by the F.A.O.: Committee on Protein Requirements (1957). The findings are compared with the mean heights, weights and subcutaneous fat of the different communities, with the incidence of protein malnutrition assessed clinically, and with the levels of haemoglobin and total plasma proteins. Enlargement of the liver may occur in protein malnutrition owing to fatty infiltration and subsequent cirrhosis (cf. Raoult, 1954; Rao, 1954), and this clinical feature has also been considered in relation to the protein consumption of these Nigerian peasant farmers, which varies considerably with the staple foodstuffs used. The quantity and quality of the dietary protein in areas where grain (mainly sorghum and millets) was the staple were found to be superior to those in areas where yams (Dioscorea spp. and Colocasia antiquorum Schott) were the most important foods.

\section{METHODS}

The methods used to assess food patterns and food consumption, and the results obtained, are fully described by Nicol (r959).

The amount of protein in the diets was computed from the F.A.O. tables (Chatfield, 1953, I954). If the information about a foodstuff was not available there, reference was made to the tables of the United States Department of Agriculture (Leung, Pecot \& Watt, 1952) and of the Medical Research Council (Platt, 1945). Analysis of certain other foods used in Nigeria not mentioned in the tables was carried out in the Department of the Government Chemist, London, to whose staff I am duly grateful. The proximate composition of a few foods was determined in the laboratories of the Nigerian Nutrition Unit in Kaduna. 
The amino-acid composition of the diets was determined as follows. The nitrogen supplied by the protein of each foodstuff was calculated from the tables with the factors given by Chatfield (1953, p. 46). From this nitrogen value the amino-acid composition of each food was computed from the tables published by the United States Department of Agriculture (Orr \& Watt, 1957). Examples of two of these calculations are given in Tables I and 2. The minimum protein requirements and safe practical allowances given in these tables are those for adult males, whereas the figures in Table 3 apply to males over 12 years of age, and include an additional allowance of protein for boys ${ }^{1} 3^{-I} 7$ years of age. Certain Nigerian foodstuffs were not recorded in the amino-acid tables, and the staff of the Government Chemist, London, kindly analysed them using microbiological techniques. From the amino-acid composition of the diets so obtained the protein score of each diet was assessed by the provisional pattern method suggested by F.A.O.: Committee on Protein Requirements (1957). In a given community the scores of the women's and children's diets did not vary significantly from that of the men's diet.

The protein requirement of each group was calculated by the methods suggested by F.A.O.: Committee on Protein Requirements (1957). The requirement in terms of reference protein was first computed, the allowances for age being made as recommended on p. 39 of the Committee's report. Boys between 13 and 17 years were allowed $0.8 \mathrm{~g}$ reference protein/day $/ \mathrm{kg}$ body-weight, and girls between $\mathrm{I} 3$ and I6 years were allowed $0.6 \mathrm{~g}$ (see curve on $\mathrm{p}$. 19 of the report). Men and women over $\mathrm{I} 7$ and $\mathrm{I} 6$ years of age respectively were allowed $0.35 \mathrm{~g}$ reference protein $/$ day $/ \mathrm{kg}$ body-weight. A reduction of this allowance was not made for old age. Women in the last trimester of pregnancy were allowed an additional ro $g$ reference protein daily. During the first 6 months of lactation women were allowed an additional $20 \mathrm{~g}$ reference protein daily, this being reduced monthly to $10 \mathrm{~g}$ at $\mathrm{I} 2$ months and to none at 2 years. From the protein score (P.S.) of the diets and the group requirement in terms of reference protein (R.P.), the minimum protein requirement (M.R.) and safe practical allowance (s.P.A.) in terms of dietary protein were calculated as follows by the method advocated by the F.A.O.: Committee on Protein Requirements (1957):

$$
\text { M.R. }=\text { R.P. } \times \frac{100}{\text { P.S. }} \text {;.P.A. }=\text { M.R. } \times I \cdot 5 \cdot
$$

Height was measured in the vertical position without footwear, and weight on a spring balance which was checked monthly against Government-inspected weights, the subjects wearing only a loin cloth. Skinfold thicknesses were measured with Longworth calipers which had blades $\mathrm{r} \cdot 2 \mathrm{~cm}^{2}$ in area and an opening pressure of $180 \mathrm{~g}$, in the following five positions: abdomen just to the right and below the umbilicus; just below the right costal margin in the mid-clavicular line; below the angle of the right scapula; the right arm midway between the shoulder and the elbow, over triceps posteriorly and over biceps anteriorly. The size of the liver was measured by palpation with the subject lying supine. The liver was not recorded as enlarged unless it was palpable $I_{2} \frac{1}{2}$ in. below the costal margin.

The incidence of protein malnutrition in children was recorded, both frank and 


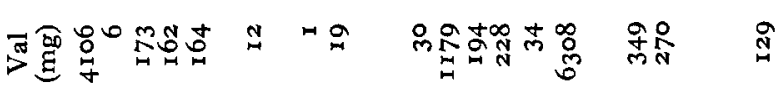

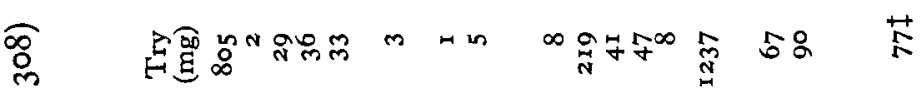

$\dot{2}$

造



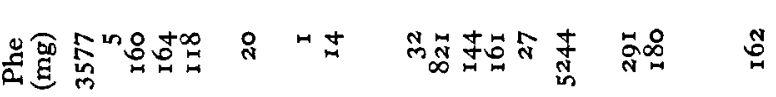



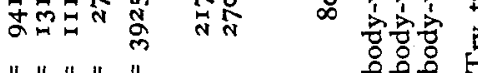

כ

है

m. || || || || || ||



건

ఫั้

ฐั

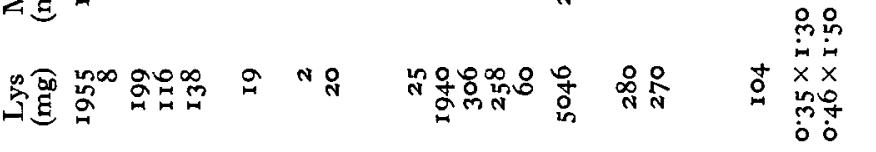

을

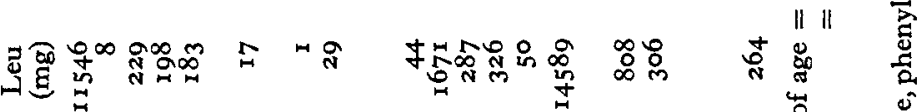

है

3



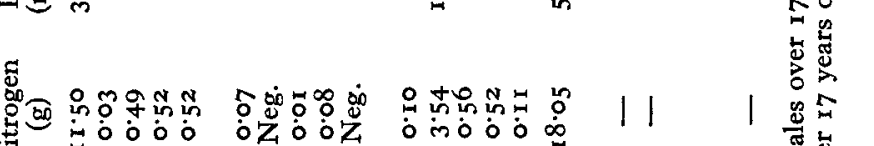

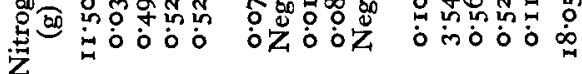



ำ

(1)

క్

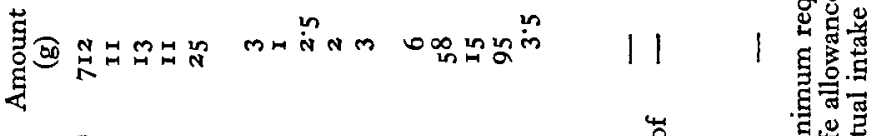



ฐัญ

हैं

$\dot{4}$

尊



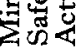

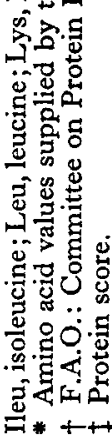






क

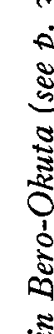

.5



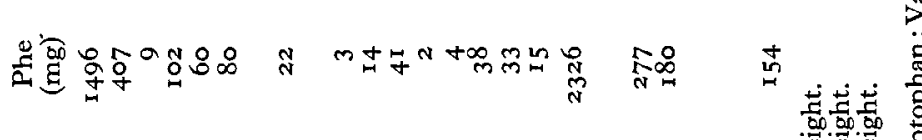

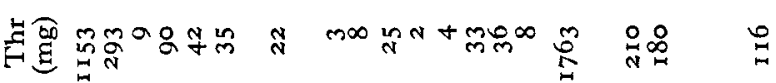

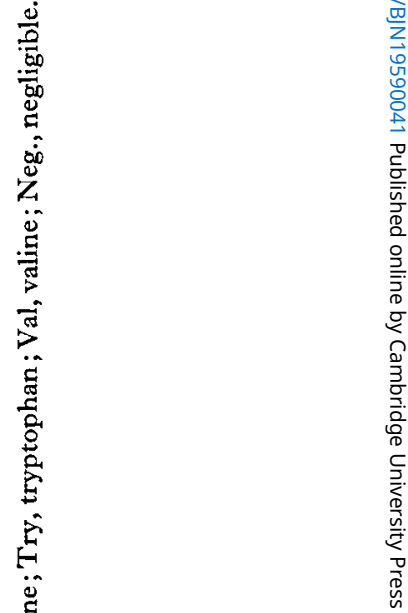

ปे

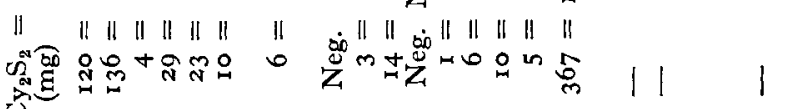

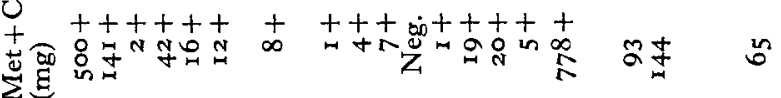



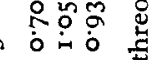

mommo mogmo

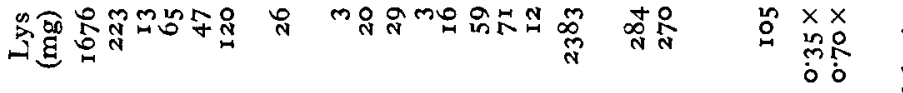

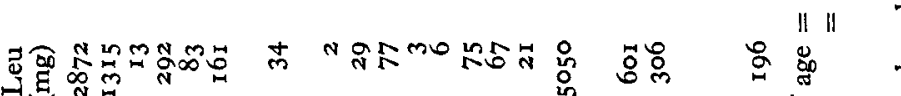



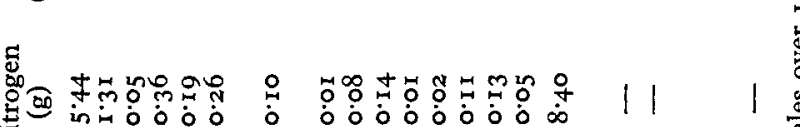
我 可㟧

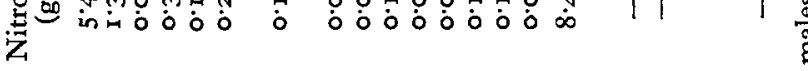

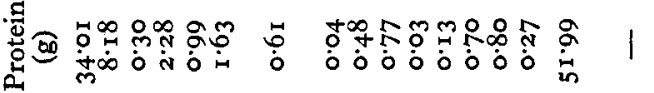

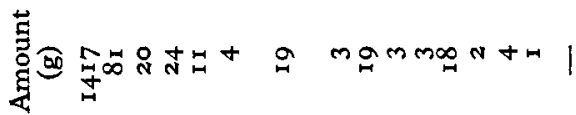

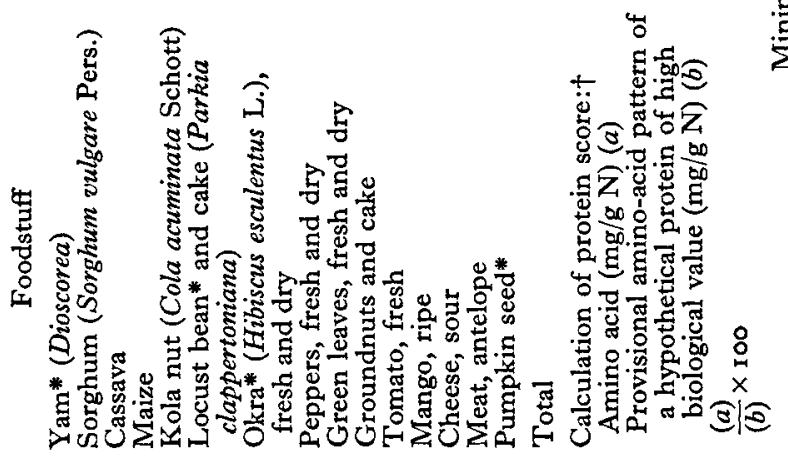


marasmic kwashiorkor being included. This nomenclature has been discussed by Waterlow (1955) and by Platt (I958). The important clinical features are irritability, stunted growth and muscular wasting, anaemia and oedema of greater or lesser degree, often associated with pallor and laxity of the curls of the hair, gastro-intestinal disturbances and dermatoses.

Total plasma proteins were determined by the copper-sulphate method (Phillips, Van Slyke, Hamilton, Dole, Emerson \& Archibald, I950; Van Slyke, Phillips, Dole, Hamilton, Archibald \& Plazin, I950). The results for total plasma proteins obtained by the Van Slyke method had been compared previously with those obtained by direct measurement and had been found to be in good agreement (Nicol, 1956). Haemoglobin levels were measured with a M.R.C. grey-wedge photometer. For all blood examinations, 8-10 $\mathrm{ml}$ blood were withdrawn from an antecubital vein into $12 \mathrm{ml}$ bottles oxalated with the residue of $0.25 \mathrm{ml}$ of $20 \%(\mathrm{w} / \mathrm{v})$ potassium oxalate. Blood was not taken from children under 7 years of age. Certain individuals refused to allow blood to be taken, and a few specimens clotted or haemolysed before they had been examined.

\section{RESULTS}

Table 3 gives the protein consumption of each of the seven communities by age and sex groups, and relates this consumption to the requirements suggested by F.A.O.: Committee on Protein Requirements (1957) and to the mean height and weight of each group. The ratios, intake:safe practical allowance and intake:minimum protein requirement, in terms of dietary protein $/ \mathrm{kg}$ body-weight are shown also. The mean daily intake of men and women over 12 years of age in the grain-eating areas (Jarawaji, Tangaza, Bunga, Tungan Maidubu and Langai) was $85 \mathrm{~g}$ protein which scored 77 , whereas in yam-eating areas (Bero-Okuta and Mbanege) the respective figures were $5^{\mathrm{I}} \mathrm{g}$ and $5^{\circ}$. The grain-eating groups consumed between $\mathrm{I}$ and $2 \frac{1}{2}$ times the safe practical allowance. The diets of the yam-eating communities provided a little more protein than the minimum requirement, but in no instance did they supply the safe practical allowance.

No significant relationship between protein intake and body-weight was observed in any age group. Adult men and women (20-50 years) from the grain-eating areas were significantly taller than those who ate yams (Table 4). Owing to lack of numbers it was only possible to compare the heights of children from 7 to 9 years of age. The children reared on sorghum and millet tended to be taller than those brought up on yams, but the difference was not significant. Women had significantly greater amounts of subcutaneous fat than men or children in both the grain and yam areas.

The incidence of clinically-detectable protein malnutrition amongst the children up to 9 years of age was $2.2 \%$ in the grain-eating communities and $5.3 \%$ in those who ate yams (Table 5), but owing to the small number of subjects the difference was not significant. Protein malnutrition was observed in only one individual over 9 years of age. She was a woman in the last trimester of pregnancy living in Mbanege, who was severely anaemic, oedematous and showed signs of vitamin B-complex deficiency. Her clinical condition improved considerably when she was given a dietary 
ॠ

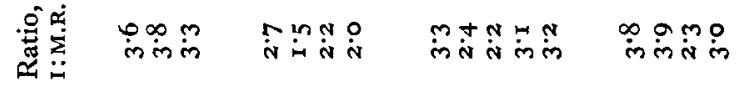

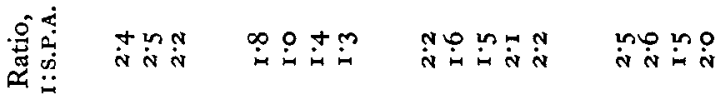



เป็

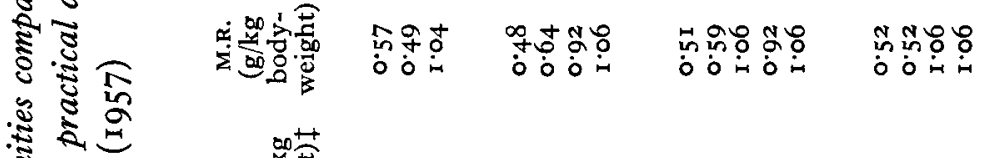



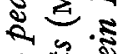

.$\frac{2}{2}$

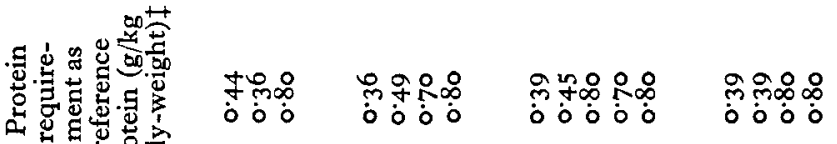

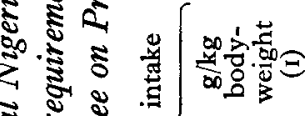

焉总

R

n

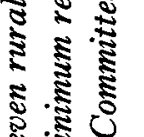

胥.

is

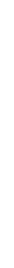

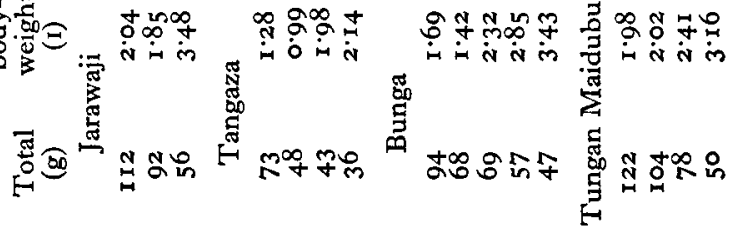

苟

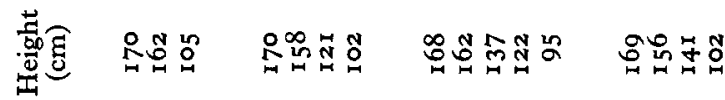

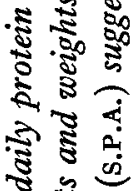


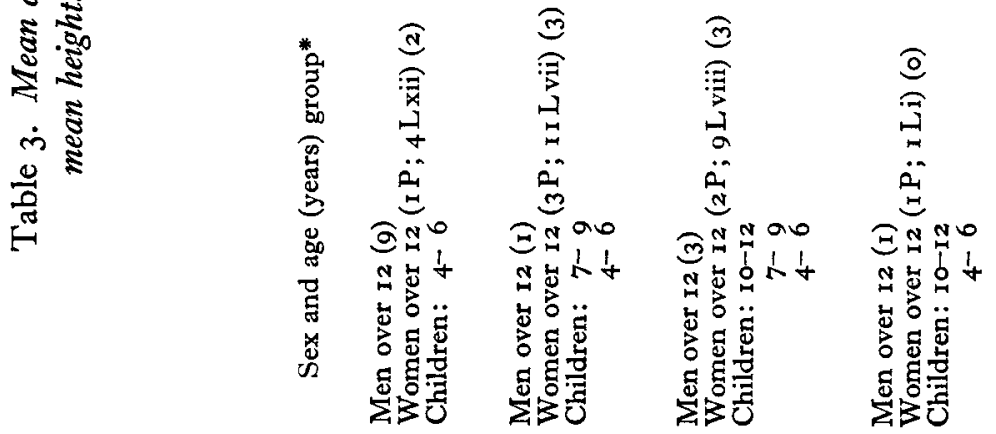
Vol. I3



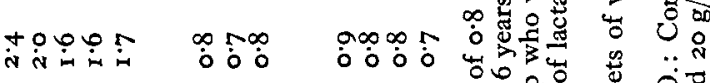

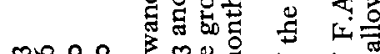

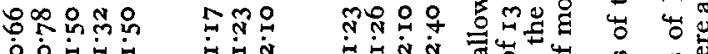

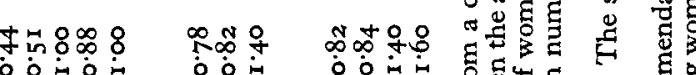

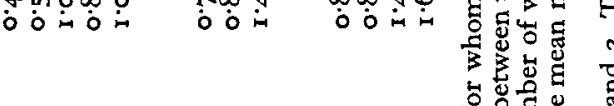

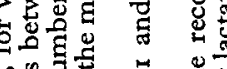

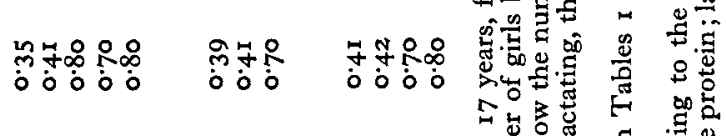

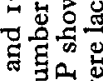

$\therefore$ in is

$. \exists \quad:$

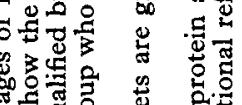



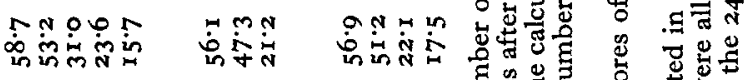



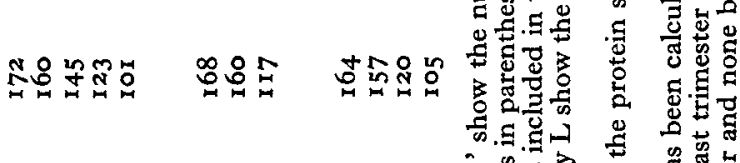

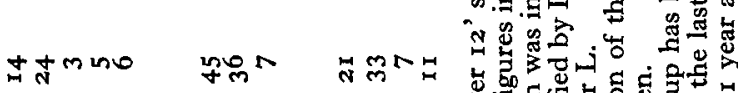

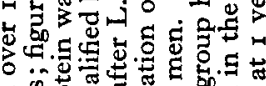

os




Table 4. Mean heights, weights and skinfold thicknesses of adult Nigerian peasants whose staple food is grain (sorghum, millets and Digitaria), compared with those for Nigerian peasants whose staple foodstuffs are yams (Dioscorea and Colocasia)

\begin{tabular}{|c|c|c|c|c|}
\hline Group & $\begin{array}{l}\text { No. in } \\
\text { group }\end{array}$ & $\begin{array}{l}\text { Height* } \\
\text { (cm) }\end{array}$ & $\begin{array}{l}\text { Weight* } \\
\quad(\mathrm{kg})\end{array}$ & $\begin{array}{l}\text { Skinfold } \\
\text { thickness* } \\
\text { (mm) }\end{array}$ \\
\hline \multicolumn{5}{|c|}{ Men 20-59 years } \\
\hline Grain areas & 107 & $171 \cdot 3 \pm 6 \cdot 75$ & $58 \cdot 6 \pm 3 \cdot 80$ & $3^{6} \pm 7$ \\
\hline Yam areas & 53 & $166.9 \pm 8.03$ & $5^{8 \cdot 0 \pm 5 \cdot 09}$ & $39 \pm 7$ \\
\hline Difference & - & $4 \cdot 4$ & 0.6 & 3 \\
\hline 3.E. of the difference & $一$ & $1 \cdot 28$ & 0.79 & $1 \cdot 2$ \\
\hline \multicolumn{5}{|c|}{ Women $20-59$ years } \\
\hline Grain areas & 127 & I $59.9 \pm 6.94$ & $5 I \cdot I \pm 4 \cdot 90$ & $52 \pm 12$ \\
\hline Yam areas & 57 & $157 \cdot 4 \pm 6.74$ & $49 \cdot 9 \pm 5.62$ & $53 \pm 14$ \\
\hline Difference & - & 2.5 & $1 \cdot 2$ & I \\
\hline S.E. of the difference & - & $1 \cdot 08$ & $0 \cdot 86$ & $2 \cdot I$ \\
\hline \multicolumn{5}{|c|}{ Children $7-9$ years } \\
\hline Grain areas & 39 & $121 \cdot 6 \pm 8 \cdot 19$ & $21 \cdot 5 \pm 3 \cdot 44$ & $29 \pm 4$ \\
\hline Yam areas & 14 & II $8.5 \pm 7.09$ & $21 \cdot 7 \pm 2 \cdot 89$ & $31 \pm 5$ \\
\hline Difference & $-\mathrm{T}$ & $3 \cdot 1$ & 0.2 & 2 \\
\hline s.E. of the difference & - & $2 \cdot 40$ & 0.98 & $I \cdot 5$ \\
\hline
\end{tabular}

* Value with standard deviation.

+ The values are means for the sum of the following five measurements made with Longworth calipers with blades $\mathrm{I} \cdot 2 \mathrm{~cm}^{2}$ and an opening pressure of $\mathrm{I} 80 \mathrm{~g}$ : abdomen, just below and to the right of the umbilicus; just below the right costal margin in the mid-clavicular line; back, just below the angle of the right scapula; right arm, midway between shoulder and elbow, posteriorly over triceps; right arm, midway between shoulder and elbow, anteriorly over biceps.

Table 5. Incidence of protein malnutrition in children less than 10 years of age from five communities whose staple foods were grain and from two communities whose staple foods were yams

\begin{tabular}{|c|c|c|c|c|c|}
\hline \multirow{3}{*}{ Community } & \multirow{2}{*}{$\begin{array}{l}\text { No. of } \\
\text { children }\end{array}$} & \multirow{3}{*}{$\begin{array}{l}\text { Staple foods } \\
\text { Grain areas }\end{array}$} & \multicolumn{2}{|c|}{$\begin{array}{l}\text { No. with protein } \\
\text { malnutrition in } \\
\text { age groups (years) }\end{array}$} & \multirow{2}{*}{$\begin{array}{l}\text { Total percentage } \\
\text { with protein } \\
\text { malnutrition }\end{array}$} \\
\hline & & & \multirow[t]{2}{*}{$0-6$} & \multirow[t]{2}{*}{$7-9$} & \\
\hline & & & & & \\
\hline Jarawaji & 21 & Sorghum & $\mathbf{I}$ & $\circ$ & $4 \cdot 8$ \\
\hline Tangaza & $5 \mathrm{I}$ & Sorghum and millets & 0 & I & $2 \cdot 0$ \\
\hline Bunga & 36 & Sorghum and millets & 0 & $\circ$ & 0.0 \\
\hline Tungan Maidubu & 12 & Sorghum and millets & $\mathbf{I}$ & $\circ$ & $8 \cdot 3$ \\
\hline Langai & 18 & Millets and Digitaria & 0 & $\circ$ & $0 \cdot 0$ \\
\hline \multirow[t]{2}{*}{ Total } & 138 & \multirow[b]{2}{*}{ Yam areas } & \multirow[t]{2}{*}{2} & \multirow[t]{2}{*}{ I } & \multirow[t]{2}{*}{$2 \cdot 2$} \\
\hline & & & & & \\
\hline Bero-Okuta & 23 & \multirow{2}{*}{$\begin{array}{l}\text { Yams (Dioscorea spp.) } \\
\text { Yams (Dioscorea, Colocasia } \\
\text { and Xanthosoma) }\end{array}$} & $\mathbf{I}$ & $\circ$ & \multirow{2}{*}{$\begin{array}{l}4 \cdot 3 \\
6 \cdot 0\end{array}$} \\
\hline Mbanege & 33 & & $\mathbf{r}$ & $\mathbf{I}$ & \\
\hline Total & 56 & & 2 & $\mathbf{I}$ & $5 \cdot 3$ \\
\hline $\begin{array}{l}\text { Total for all } \\
\text { communities }\end{array}$ & 194 & & 4 & 2 & $3 \cdot I$ \\
\hline
\end{tabular}

The difference between the incidence of protein malnutrition in children in the grain and in the yam areas is not statistically significant $(P>0.05)$. 
Table 6. Mean protein intake, protein score, haemoglobin and total plasma-protein concentration of Nigerian peasant communities living in areas where grains (sorghum, millet and Digitaria) were the staple food, compared with those of similar communities living in areas where yams (Dioscorea and Colocasia) were the staples

\begin{tabular}{|c|c|c|c|c|c|}
\hline Group & $\begin{array}{l}\text { No. in } \\
\text { group }\end{array}$ & $\begin{array}{c}\text { Protein } \\
\text { intake } \\
\text { (g) }\end{array}$ & $\begin{array}{l}\text { Protein } \\
\text { score* }\end{array}$ & $\begin{array}{c}\text { Total plasma } \\
\text { proteint } \\
(\mathrm{g} / \mathrm{ro0} \mathrm{ml})\end{array}$ & $\begin{array}{l}\text { Haemoglobin } \dagger \\
\quad(\mathrm{g} / \mathrm{r} 00 \mathrm{ml})\end{array}$ \\
\hline \multicolumn{6}{|c|}{ Children $7-9$ years } \\
\hline Grain areas & 32 & 50 & 77 & $7.9 \pm 0.49$ & II $\cdot 7 \pm I \cdot 35$ \\
\hline Yam areas & 14 & 37 & 50 & $7.9 \pm 0.40$ & I I $3 \pm 0 \cdot 7 I$ \\
\hline \multicolumn{6}{|c|}{ Males over I 2 years } \\
\hline Grain areas & 128 & IOI & 77 & $8 \cdot 1 \pm 0.53$ & $13 \cdot 0 \pm 1 \cdot 77$ \\
\hline Yam areas & 59 & 55 & 50 & $8 \cdot 0 \pm 0.62$ & $13.5 \pm 1 \cdot 62$ \\
\hline
\end{tabular}

Females over 12 years (neither in last trimester of pregnancy nor lactating) $\ddagger$

\begin{tabular}{|c|c|c|c|c|c|}
\hline $\begin{array}{l}\text { Grain areas } \\
\text { Yam areas }\end{array}$ & $\begin{array}{r}127 \\
51\end{array}$ & $\begin{array}{l}74 \\
48\end{array}$ & $\begin{array}{l}77 \\
50\end{array}$ & $\begin{array}{l}7.8 \pm 0.59 \\
7.8 \pm 0.76\end{array}$ & $\begin{array}{l}\text { II } \cdot 7 \pm I \cdot 48 \\
I 2 \cdot I \pm I \cdot 82\end{array}$ \\
\hline \multicolumn{6}{|c|}{ Females in the last trimester of pregnancy $\downarrow$} \\
\hline $\begin{array}{l}\text { Grain areas } \\
\text { Yam areas }\end{array}$ & $\begin{array}{l}8 \\
2\end{array}$ & $\begin{array}{l}74 \\
48\end{array}$ & $\begin{array}{l}77 \\
50\end{array}$ & $\begin{array}{l}7.4 \pm 0.47 \\
6.2 \pm 0.70\end{array}$ & $\begin{array}{r}10.2 \pm 0.79 \\
8.8 \pm 1.60\end{array}$ \\
\hline \multicolumn{6}{|c|}{ Females lactating $\ddagger$} \\
\hline $\begin{array}{l}\text { Grain areas } \\
\text { Yam areas }\end{array}$ & $\begin{array}{l}25(7) \\
\text { I I (12) }\end{array}$ & $\begin{array}{l}74 \\
48\end{array}$ & $\begin{array}{l}77 \\
50\end{array}$ & $\begin{array}{l}7.9 \pm 0.60 \\
7.8 \pm 0.65\end{array}$ & $\begin{array}{l}\text { II.6 } 1 \mathrm{r} \cdot 85 \\
12 \cdot 0 \pm \mathrm{r} \cdot 08\end{array}$ \\
\hline
\end{tabular}

* See Table 3.

+ Value with standard deviation.

I It was not possible to differentiate between the food consumption of women who were pregnant or lactating and the rest. Figures in parentheses are the mean number of months of lactation.

supplement of groundnut flour, and she delivered and nursed her child satisfactorily, giving up the groundnut-flour supplement I month post partum.

The concentrations of total plasma protein and haemoglobin were considered in relation to the quantity and quality of protein ingested, to age and sex, to the last trimester of pregnancy, and to lactation and its duration (Table 6). The mean concentrations of total plasma protein of children aged 7-9 years and of men and of the women not in the last 3 months of pregnancy were the same $(7 \cdot 8-8 \cdot 1 \mathrm{~g} / 100 \mathrm{ml})$ in both grain-eating and yam-eating communities. Lactation was not found to depress the plasma-protein concentration below this level. Pregnant women whose staple foods were grain or yams had mean plasma-protein concentrations of 7.4 and $6.2 \mathrm{~g} / \mathrm{100 \textrm {ml }}$ respectively. The mean haemoglobin concentration in men over 12 years of age was $\mathrm{I} 3.0 \mathrm{~g} / 100 \mathrm{ml}$ in the grain areas and $\mathrm{I} 3.5 \mathrm{~g} / 100 \mathrm{ml}$ in the yam areas, the corresponding figures for non-pregnant and lactating women being $1 \mathrm{I}^{\cdot} 7^{\wedge}$ and $12 \cdot \mathrm{I} \mathrm{g} / 100 \mathrm{ml}$. In children 7-9 years of age the haemoglobin concentration was about the same as that of the non-pregnant and lactating women. Women in the last trimester of pregnancy whose staple foods were sorghum and millets had a mean haemoglobin concentration of $10.2 \mathrm{~g} / 100 \mathrm{ml}$, the figure for the corresponding women in the yam-eating communities being $8.8 \mathrm{~g} / 100 \mathrm{ml}$. The number of women in the last 3 months of pregnancy was very small.

The incidence of hepatomegaly and of malarial parasitaemia, schistosomiasis and 


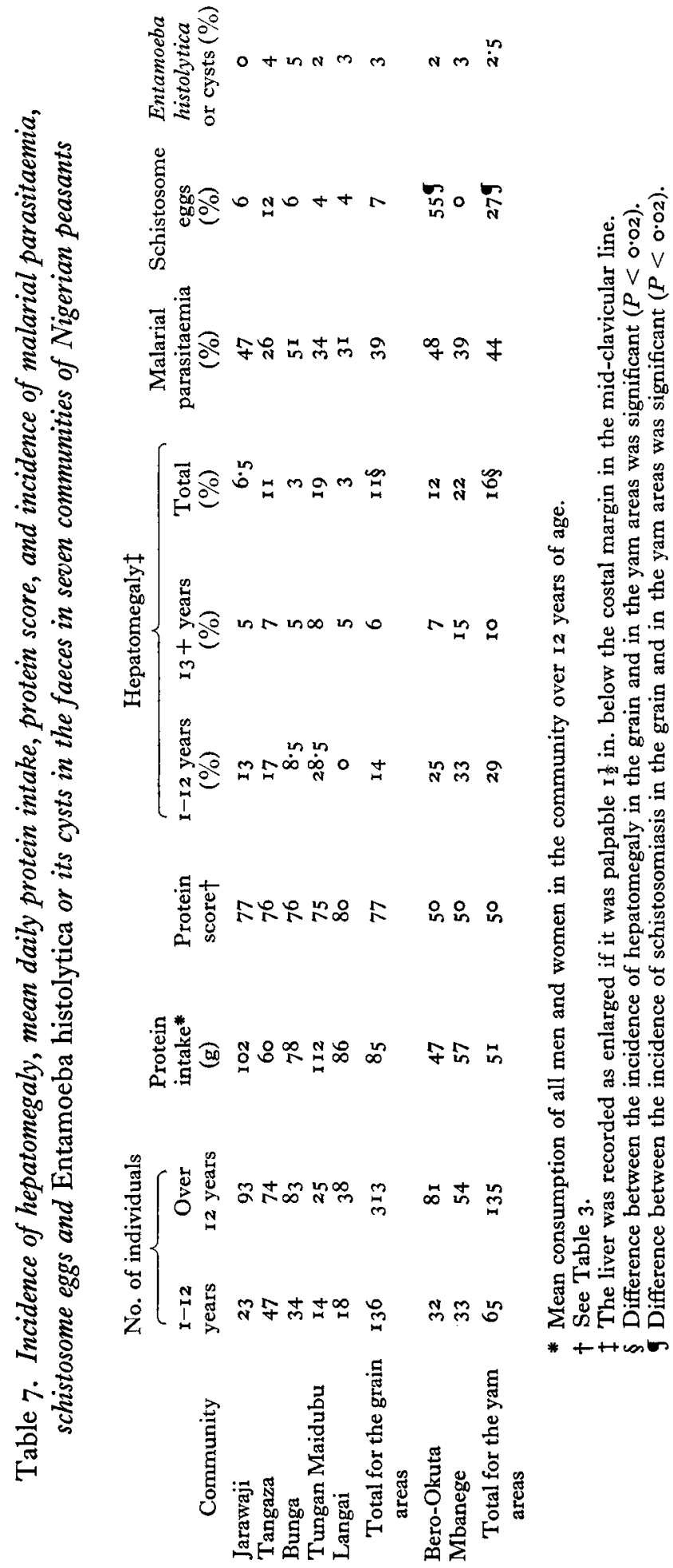


amoebiasis is shown in Table 7. The mean incidence of hepatomegaly was $16 \%$ among those communities whose protein consumption was low and of poor quality, and $1 \mathrm{I} \%$ in those people whose diets provided larger amounts of protein of better quality. However, malaria was holoendemic in all areas, and schistosomal infestation was higher in the yam areas than in the grain areas. Moreover, the second greatest incidence of hepatomegaly occurred in the community with the highest protein intake, so it is impossible to assess the significance of this clinical feature in relation to protein consumption.

\section{DISCUSSION}

It is important to point out that the methods suggested by F.A.O.: Second Committee on Calorie Requirements (1957) and F.A.O.: Committee on Protein Requirements (1957) use the mean weights of the different age and sex groups forming a community as a basis for assessing its needs for calories and protein. The mean weights of Nigerian men, women and children are all less than those of the F.A.O. reference man and woman. If it is considered desirable that the African weights should be as great as these references, then the African requirements for calories and protein would be greater than those reported in this paper.

Those communities that traditionally use sorghum and millets as staple foods normally ingested amounts of protein of sufficiently good quality to supply from I to $2 \frac{1}{2}$ times the safe practical allowance. In areas where yams were the staple food the diets provided slightly more than the minimum protein requirement. The mean height of men and women between 20 and 29 years of age whose staple food was grain, namely $165 \mathrm{~cm}$, was found to be the same as that of men and women of European derivation (Pett, 1955). That of men and women from the yam-eating areas was $162 \mathrm{~cm}$. The mean weights of men and women from both areas were the same in spite of marked differences of calorie and protein intakes, and it was suggested in the previous paper (Nicol, 1959) that different levels of energy expenditure accounted for this finding.

The incidence of protein malnutrition in children was higher in the yam-eating communities than in those whose staple food was grain, but the difference was not significant because the overall incidence was low. With the exception of the pregnant woman mentioned above, definite clinical protein malnutrition was not diagnosed in any individual over 9 years of age.

The mean plasma-protein concentrations of the children, the men and all women who were not in the last trimester of pregnancy were the same (about $7.9 \mathrm{~g} / \mathrm{I00} \mathrm{ml}$ ) in both areas. Holmes, Stanier, Semambo \& Jones (1951) reported the same high level of plasma protein in a group of apparently healthy African peasants in Uganda. Such values are well above the ranges accepted as normal in England (6.7-7.7 g/ $100 \mathrm{ml}$ (King, 195 I)) and in North America $(7.2 \pm 0.35 \mathrm{~g} / 100 \mathrm{ml}$ (Sunderman \& Boerner, r949)). Stanier \& Holmes (1954), Ganzin (1954) and Close (1954) found that such concentrations of total plasma protein in Africans were accompanied by albumin:globulin ratios of about $0 \cdot 8$, this low value being due to increased $\gamma$-globulin rather than to low levels of albumin. Edozien (1958) reported a lower mean concentration of 
total plasma protein $(6.95 \pm 0.4 \mathrm{~g} / \mathrm{ro0} \mathrm{ml})$ in a mixed group of healthy Nigerian professional and business men, labourers and peasant farmers, the albumin: globulin ratio being $\mathrm{I} \cdot 0 \mathrm{I} 4 \pm 0 \cdot 18$.

As in England, the haemoglobin concentration of African men was found to be higher than that of their women and children, but these levels were all below the normal European ranges. This low value is not surprising in view of the prevalence of malaria and intestinal and other infestations. An unexpected finding was that the mean haemoglobin concentration of the men and of the women not in the last trimester of pregnancy was slightly higher in those groups whose diet provided an average $5 \mathrm{I} \mathrm{g}$ protein which scored 50 than in those whose diet supplied $85 \mathrm{~g}$ protein of score 77 . The mean daily iron intake of the latter group was $34 \mathrm{mg}$, whereas that of the former was $20 \mathrm{mg}$.

It was pointed out in the previous paper (Nicol, I959) that the method used to measure food consumption could not differentiate between that of pregnant, lactating and other women without disturbing their normal eating habits to a considerable extent. It is possible, therefore, that pregnant and lactating women ate more than the other women with whom they often shared the same calabash. However, there is no doubt that the quality and quantity of protein eaten by the pregnant and lactating women was much higher in the grain areas that it was in the yam areas. The mean concentrations of haemoglobin and plasma protein of women in the last trimester of pregnancy in both areas were lower than those of the other women, including those who were lactating, the difference being most marked for women from the yam areas. The number of women in the last trimester was so small that the difference is of doubtful significance. It is possible that the low figures recorded were the result of the physiological increase in plasma volume which occurs normally in pregnancy (Hytten \& Duncan, 1956). Woodruff $(1951,1955)$ has described anaemia in pregnant African women, and attributed it to lack of dietary protein of good quality. It is impossible to determine from my investigations whether 'physiological haemodilution of pregnancy' was entirely responsible for the low haemoglobin levels found in the women in the last trimester, or if lack of dietary protein played a part. Certainly the difference between the protein intakes of the two groups of lactating women did not affect their concentrations of total plasma protein and haemoglobin.

\section{Conclusions}

It is noteworthy that so little difference was found between the clinical condition of the two groups of African peasants whose diets supplied, on the one hand, a daily average of $85 \mathrm{~g}$ protein, which scored 77 according to the provisional amino-acid pattern recommended by F.A.O.: Committee on Protein Requirements (1957), and, on the other hand, $5^{\mathrm{I}} \mathrm{g}$ protein which scored $5^{\circ}$. A small difference in adult height and a slightly higher incidence of protein malnutrition in young children in the yam-eating communities were the only positive findings.

It seems reasonable to assume that a daily intake by an adult of $5 \mathrm{x} g$ protein of score 50 , slightly more than the minimum requirement, is as satisfactory for normal adult maintenance in such rural tropical communities as an intake of $85 \mathrm{~g}$ which 
scores 77 , this level being $2 \cdot 3$ times the safe practical allowance. My findings do not indicate that women suffering from the stresses of pregnancy and lactation fare worse clinically on the lower than on the higher protein intake.

Finally, it seems justifiable to conclude that the safe practical allowance of dietary protein suggested by F.A.O.: Committee on Protein Requirements (I957) is unnecessarily high.

\section{SUMMARY}

I. The quantity and quality of the protein consumed by five communities of Nigerian peasant farmers whose staple foods were sorghum and millets were compared with those of two farming communities whose staple foods were yams of different species.

2. The mean daily protein consumption of men and women over 12 years of age whose staple foods were sorghum and millets was $85 \mathrm{~g}$, with a protein score (F.A.O.: Committee on Protein Requirements, 1957) of 77. The corresponding figures for those eating yams were $5^{\mathrm{I}} \mathrm{g}$ and $5^{\circ}$.

3. In the grain-eating areas this level of protein consumption provided $I \cdot 5-2 \cdot 5$ times the safe practical allowance recommended by F.A.O. In the yam-eating areas the diets supplied a little more than the minimum protein requirement, but they never provided the safe practical allowance.

4. The adults 20-59 years of age whose staple food was grain were significantly taller than those whose staple food was yams. The weights and subcutaneous fat of men, women and children did not vary significantly with the amount of protein ingested.

5. The overall incidence of protein malnutrition in children up to 9 years of age was $3.1 \%$. The incidence amongst the grain-eating peoples was $2.2 \%$ and in the yameating communities $5.3 \%$. The difference was not statistically significant $(P>0.05)$.

6. The concentrations of haemoglobin and plasma protein of men and women over I 2 years and of children over 7 years of age were the same whichever level of protein they consumed.

7. The concentrations of haemoglobin and plasma protein of women in the last trimester of pregnancy were lower than those of women who were neither in the last trimester of pregnancy nor lactating, the difference being more marked in the women on the low level of protein intake.

I am indebted to the Chief Medical Adviser to the Federal Government of Nigeria for permission to publish this paper. It is a pleasure to acknowledge the help of Mallam Abubaker Zukogi Bida and the members of the Medical Field Units of the Northern and Eastern regions of Nigeria, and $\mathrm{Mr} \mathrm{S}$. Aigbokhaevbo's clerical assistance.

\section{REFERENCES}

Chatfield, C. (1953). F.A.O. nutr. Stud. no. 3, and ed.

Chatfield, C. (1954). F.A.O. nutr. Stud. no. I 1.

Close, J. (1954). In Malnutrition in African Mothers, Infants and Young Children. Report of the Second Inter-African (CCTA) Conference on Nutrition, Gambia, 1952, p. 198. [B.S.Platt, editor.] London: H.M. Stationery Office.

Edozien, J. C. (1958). W. Afr. med. F. 7, 121 .

F.A.O.: Committee on Protein Requirements (1957). F.A.O. nutr. Stud. no. I6. 
F.A.O.: Second Committee on Calorie Requirements (1957). F.A.O. nutr. Stud. no. I5.

Ganzin, M. J. (1954). In Malnutrition in African Mothers, Infants and Young Children. Report of the Second Inter-African (CCTA) Conference on Nutrition, Gambia, I952, p. 200. [B. S. Platt, editor.] London: H.M. Stationery Office.

Holmes, E. G., Stanier, M. W., Semambo, Y. B. \& Jones, E. R. (195 I). Trans. R. Soc. trop. Med. Hyg. 45, 37I.

Hytten, F. E. \& Duncan, D. L. (1956). Nutr. Abstr. Rev. 26, 855.

King, E. J. (195I). Micro-analysis in Medical Biochemistry, and ed. London: J. and A. Churchill.

Leung, W. W., Pecot, R. K. \& Watt, B. K. (1952). Agric. Handb. U.S. Dep. Agric. no. 34.

Nicol, B. M. (1956). W. Afr. med. F. 5, 157.

Nicol, B. M. (1959). Brit. F. Nutr. 13, 293.

Orr, M. L. \& Watt, B. K. (1957). Home Econ. Res. Rep. U.S. Dep. Agric. no. 4.

Pett, L. B. (1955). Amer. F. publ. Hlth, 45, 862.

Phillips, R. A., Van Slyke, D. D., Hamilton, P. B., Dole, V. P., Emerson, K. Jr. \& Archibald, R. M. (1950). F. biol. Chem. 183, 305.

Platt, B. S. (1945). Spec. Rep. Ser. med. Res. Coun., Lond., no. 253.

Platt, B. S. (1958). Proc. Nutr. Soc. 17, xl.

Rao, M. V. R. (1954). In Malnutrition in African Mothers, Infants and Young Children. Report of the Second Inter-African (CCTA) Conference on Nutrition, Gambia, 1952, p. 358. [B. S. Platt, editor.] London: H.M. Stationery Office.

Raoult, A. (1954). In Malnutrition in African Mothers, Infants and Young Children. Report of the Second Inter-African (CCTA) Conference on Nutrition, Gambia, 1952, p. 37. [B. S. Platt, editor.] London: H.M. Stationery Office.

Stanier, M. W. \& Holmes, E. G. (1954). Brit. F. Nutr. 8, 155 .

Sunderman, F. W. \& Boerner, F. (1949). Normal Values in Clinical Medicine. Philadelphia and London: W. B. Saunders Co.

Van Slyke, D. D., Phillips, R. A., Dole, V. P., Hamilton, P. B., Archibald, R. M. \& Plazin, J. (I950). 7. biol. Chem. $\mathbf{1 8 3}, 349$.

Waterlow, J. C. (editor) (1955). Protein Malnutrition: Proceedings of a Conference in Famaica, 1953 Rome: FAO/WHO/Josiah Macy Jr. Foundation.

Woodruff, A. W. (1951). Brit. med. F. ii, 14I5.

Woodruff, A. W. (1955). Brit. med. F. i, 1297.

\title{
The determination of body composition of living animals
}

\section{The daily endogenous creatinine excretion as a measure of body composition in rats}

\author{
BY I. KUMAR,* D. G. LAND† AND A. W. BOYNE \\ Rowett Research Institute, Bucksburn, Aberdeen
}

(Received 5 December I958-Revised I3 April 1959)

In many nutritional and metabolic experiments it is desirable to know the mass of one or both of the main components of the animal body, namely storage, or non-essential, fat and lean body mass (L.B.M.) (Behnke, I94I-2). These components, together with the gut contents, make up the live weight of the animal. Fat is the most variable of the three, and in many nutritional and dietary experiments its size is important. However, as it is not an actively metabolizing tissue, for some purposes it is often sufficient to know the size of the L.B.M. only. The constancy of the composition of the L.B.M. is

\footnotetext{
* Present address: Department of Animal Nutrition, Postgraduate College of Animal Sciences, Izatnagar (U.P.), India.

$\uparrow$ Present address: Ministry of Agriculture, Fisheries and Food, Experimental Establishment, Greyhope Road, Aberdeen.
} 